\title{
Preference Pattern for Mobile Phone and Conventional Tools in Task Performance by Students of Delta State University, Abraka, Nigeria
}

\author{
Emmanuel Ufuophu-Biri, PhD \\ Senior Lecturer and Head of Department, Mass Communication, Delta State University, Abraka, Nigeria \\ Email: eubiri@yahoo.co.uk \\ Lucky Ogheneruemu Ojoboh, PhD \\ Lecturer, Department of Mass Communication, Delta State University, Abraka, Nigeria \\ Email ojobohluckyogheneruemu@yahoo.com
}

Doi:10.5901/mjss.2017.v8n2p281

\section{Abstract}

\begin{abstract}
Mobile phones have become very popular among people in different countries of the world and apart from the traditional role of making and receiving of calls; they have been adopted for several other uses. Its use for those activities tends to pose challenge to the conventional media tools that are used traditionally to perform those activities. The study thus aims at determining the pattern of mobile phone usage by students of Delta State University, Abraka; their preference pattern for mobile telephone and conventional media tools in carrying out certain activities; and the implication of their use of mobile telephone on conventional media toolsThe study adopted the Technology Acceptance Model (TAM), which explains how a person comes to accept and use an information technology. Survey and questionnaire were used as the research method and instrument respectively. The data were analyzed with descriptive statistics. The study found that the students preferred using mobile phones to perform tasks that were originally performed with conventional media tools; and the use of mobile phone by the students also suggested a diminishing patronage of conventional media tools. The study recommends that providers of those conventional media tools should improve on their services to avoid losing patronage, and they should make their products and services adaptable to mobile phone users in order to boost patronage.
\end{abstract}

Keywords: mobile phone usage, conventional tools, task performance, Delta State University, preference pattern.

\section{Introduction}

Communication seems to be one of the most important needs of man as it is required in all facets of human endeavours. Thus Baran (2002) asserts that communication embraces all aspects of human endeavours. The importance man attaches to communication has, perhaps, motivated man to invent different technologies to perfect communication both at the interpersonal and mass communication levels. One of such recent invention is digital mobile telephone which is used for the Global System of Mobile Communication (GSM), Multiple Division Access Code (CDMA), Satellite Phone (SP) and Internet Phone (IP).

The invention of the mobile phone is advancement on the technology of distant communication which began in 1830 with the invention of the telegraph in England and United States of America independently. Other breakthroughs in communication that followed the telegraph were the telephone invented by Alexander Graham Bell in 1876; Guglielmo Marconi patenting of wireless telegraph in 1897; and the making of the first telephone call round the world in 1935.

Lacohée, Wakeford and Pearson (2003) trace the history of mobile phone to the earliest cellular phones that were large, heavy and useable only in vehicles with the engine of the vehicle running. However, between 1973 and 1983, several prototypes of mobile cellular phone were made and which could be used without being plugged to vehicles. Then in the 1990s mobile phone switched from the initial $1 \mathrm{G}$ analog network to $2 \mathrm{G}$ digital networks and by 2001, 3G network was introduced and it enabled mobile phone to perform several other functions such as internet access, text messaging and sharing videos and photos. They also explain that by 1990 much improvement had been made on mobile cellular phone which led to massive advancement in digital mobile phone technology.

In 2001 the first GSM phone network provider in Nigeria -Econet- started operation and was followed almost immediately by other mobile telephone network providers such as MTN, Mtel, Glo and CMDA providers which included Multilink and Visa phone. Modern era mobile phone is digital and different from what obtained as the modern mobile 
phone is capable of carrying data and performing several tasks that none of its predecessors could perform (Atala and Umar, 2006). The digital telephone facilitates effective instant communication and performance of sundry tasks.

It has many advantages such as cost effectiveness, portability, accessibility and sundry task performance. However, Okoro and Barikui (2006) assert that all the previous problems associated with telephony in the pre-digital telephony era have been resolved by the advent of current telephone technology regime.

The benefits of the digital mobile telephone seem to be overwhelming and probably, have over-shadowed the landlines provided by NITEL as could be deduced from a research finding by Akpan (2005) which showed that $82.2 \%$ of the students of the University of Nigeria, Nsukka, who responded preferred digital mobile phones to landlines. They gave the following reasons for their preference: mobile phone is more cost effective to maintain, cheaper to install; provides more privacy, more portable and is used to perform several functions.

Oliseh and Igun (2006) also emphasize that no other telephone system that existed before the modern digital telephone era has been able to provide services such as text messages, Internet services, multimedia messaging service (MMS), games, internet services and students of higher institutions of learning have come to prefer mobile phones. The preference of mobile phones, according to them, could have negative consequence on some conventional/traditional tools of communication. Modern digital mobile phone devices, according to Ronoh (2014), have the advantage of performing several other tasks. They could be used as calculators, books, mail services, watches, and calendar, radio, music, camera, cinema and invitation cards among others.

Patel and Rathod (2011) also assert that many users of digital mobile phone devices seem to prefer using them to perform tasks which have hitherto been the exclusive preserve of certain conventional tools. For instance,the calculator which is meant for calculation and other mathematical tasks is currently threatened by mobile phone devices which can also be used as a calculator.

Corroborating this assertion, Mogambi (2015) adds that there is the issue of preference for mobile phone usage and conventional tools in performing tasks that were hitherto performed by other conventional tools and the preference pattern seems to be in favour of mobile phone. Cardon (2014) however argues that the use of mobile phone to perform other tasks other than telephoning could have negative implications on the original tools that are designed for those tasks.

For instance many people use mobile phone for conferencing, teleconferencing, photography, videoing and calculation, notebook, several Internet functions, banking, television, radio, movies, invitation cards, the Bible, Quran, dictionary, social media, clock, organizer, games, seasonal greeting cards, calendar, multi-media player, etc.

Cardon states that the emerging trend of using mobile phones to perform several tasks could shift attention from the conventional tools that are originally meant to perform those tasks This study covers the undergraduate students of the Delta State University, Abraka. Delta State University, Abraka, is a state university with three campuses at Abraka (the main campus), Anwai and Oleh. The study covers only the students in the Abraka campus.

\section{Objectives of the Study}

This work aims at determining:

1. the pattern of mobile phone usage by students of Delta State University, Abraka;

2. the preference of Delta State University students for mobile telephone and conventional media tools in carrying out certain activities; and

3. the implication of the use of mobile telephone by students of Delta State University, Abraka on conventional media tools.

\section{Research Questions}

The following research questions guided the study:

1. What is the pattern of mobile phone usage by students of Delta State University, Abraka?

2. What is the preference of Delta State University students for mobile telephone and conventional media tools in carrying out certain activities?

3. What is the implication of the use of mobile telephone usage by students of Delta State University, Abraka on conventional media tools? 


\section{Literature Review}

Mobile telephone, which is totally digital, is used by different people in several ways and for different purposes other than the traditional making and receiving of calls and short messaging. According to Muhammed, Umaru, Ahmed (2016), the mobile technology is about the fastest and most understated paradigm shift the world has ever witnessed. People use it to connect other people and sometimes for commercial, industrial and entertainment purposes. Baron (2011) found in a study of university students across five different countries that students adopted mobile phones for different reasons including telephoning, texting, social networking, and commerce among others.

The study also suggested that the students preferred using mobile phones to perform several tasks which are the traditional functions of other categories of conventional media tools. A study by Lenhart, Ling, Campbell \& Purcell (2010) on 800 young American boys and girls within the age range of 12 and 17 years, indicated they used mobile phone extensively for different purposes and they preferred mobile phones to other traditional media tools.

Some of these conventional/traditional tools include calculator, diary, planner, clock, radio, television, books, Bible, internet, flash light, photography and videoing. The usage of mobile phones, according them could have negative effects on the traditional tool meant for those tasks. Kasesniemi (2003) and Kun-Hsi (2010) emphasize, separately, that mobile phones are very popular among young people, especially university students who find pleasure in using mobile phones for task performance at the disadvantage of the traditional tools meant for those tasks.

Walker (2014) explains that mobile phone devices have taken over, to a large extent, the means of entertainment and the functions of other traditional media tools. He explains that mobile phone devices have become music collection and player, movie library, alarm clock, calendar, social networks, camera, sketch book, address book, gaming console, notepad, radio, television and many more. People use mobile phones to perform the above tasks at the expense of traditional tools that are actually used to perform them. Many mobile phone users have adopted mobile phones for newspapers, magazines, books, and this could have great reduction on the level at which people had hitherto used those conventional media of communication.

Ling (2004), Karim and Oyefolahan (2009) Pew Research Center (2010) and Walker, (2011) separately assert that the use of mobile phone devices have taken over the traditional roles of many conventional media tools. For instance, mobile phone devices are used to do several things apart from making calls and sending text messages. This has also made the mobile phone an all - in - one device that is used in multi-task performance.

Cardon (2014) discloses that in China, mobile phones are used to perform several tasks and mobile phones have become mainstream devices. The use of mobile phone in China is thus tending to override many other mainstream tools that are used to perform tasks for which mobile phones are currently used. Mobile phone SMS, which has become very increasingly used by mobile phone subscribers, according to Reid and Reid (2004) has the potential and capability to eventually erase face-to-face interaction and impact negatively on grammar by frequent users.

The popularity of mobile phone has made it to be tagged the 'fourth screen' by Ashiq, Mahmood \& Abdul (2013). They opine that the mobile phone is the fourth screen after cinema, television and internet. Apart from being the fourth screen, it performs the functions of the rest three screens -cinema, television and internet. In addition to serving as the fourth screen, Zulkefly and Baharudin (2009) and Halder (2015) observe that mobile devices have been significantly adopted for educational purpose by many undergraduate students who use it to explore e-libraries, e-book, Wikipedia, blogs, social media sites for educational purposes.

Kun-Hsi (2010) also points out that students use mobile phones to explore web based contents, share them, collaborate with others, thus mobile phone can also be used for distant learning. Mobile phone usage thus seems to have gained much patronage among undergraduate students. For instance, Ronoh (2012) found in a study on the usage patterns of mobile phones amongst university students in Kenya, that the students, apart from using mobile phones for simple uses such as making calls and texting, they use them to perform various other tasks. The students also use the mobile phones according to their lifestyles and other needs such as social interaction, entertainment and learning. A study conducted by Adomi (2006) on mobile phone usage pattern of library and information science students at the Delta State University, Abraka, Nigeria found that the students used mobile phones in a variety of ways and for various reasons ranging from simple calls and SMS to financial, love, academic, politics, sports and religious matters.

Similar to the finding of Adomi is that of Patel and Rathod (2011) who found students in India to use mobile phone extensively for several purposes. The study also found that the students preferred using mobile phone to perform tasks which are ordinarily performed with other conventional tools.

The foregoing review has shown how university undergraduate students use mobile phones in the performance of different tasks. The review suggests that undergraduate students are very interested in using mobile phone for multitasking 


\section{Theoretical Framework}

The study adopts the Technology Acceptance Model (TAM), an information system theory, which explains the acceptance and use of a technology by the user. The theory recognizes that there are several factors that determine how and when people will use a technology of which the main ones are Perceived Usefulness (PU) and Perceived Ease-ofUse (PEOU).

The user of the technology has to be convinced of the usefulness as well how easy it would be to use it when compared to other existing or competing technologies. TAM which was developed by Fred Davis and Richard Bagozzi in 1989 strongly maintains that the successful use of a particular technology is largely dependent on its acceptance and adoption by the user. Corroborating the postulations of TAM, Bagozzi (2007), emphasizes that once a person has accepted a technology sucha person would use it. This work is centred on mobile phone use and going by this theory the usage of the mobile phone, may therefore primarily be dependent on the user's acceptance. This theory is relevant to this study; it is therefore adopted for the study.

\section{Methodology}

The survey method was adopted, while questionnaire was the instrument used. The population comprises the entire undergraduate students of the Delta State University in the main campus at Abraka. The population was approximately 18768 students. This is sourced from the University's Department of Information and Communication Technology. The cluster and simple random systems were used as sampling procedures. The population was clustered into the seven faculties namely Arts, Basic Medical Sciences, Education, Pharmacy, Sciences and Social Sciences.

Five faculties were selected and from each faculty, four departments were also chosen. From each of the selected departments, 100 students were sampled using simple random sampling. The sample size was therefore 2000. The researcher hired the service of research assistants to administer copies of the questionnaire as well as to retrieve them. The data gathered were analyzed using table and percentages.

\section{Results and Discussion}

Out of the 2000 copies of questionnaire administered, 1,820 were retrieved which represents $91 \%$. The results are presented on the table 1 below.

Table 1. Use of mobile phone and conventional media tools for task performance

\begin{tabular}{|l|l|c|c|}
\hline Activities/tasks & Conventional media tools & Mobile Phone & Total (N) \\
\hline Telephoning & Conventional land line phone 00 (00\%) & $1,820(100 \%)$ & 1,820 \\
\hline Letter posting & Normal postal system 213 (11.7\%) & $1607(88.3 \%)$ & 1,820 \\
\hline Receiving money from parents and others & Poster order, money order 383 (21.0\%) & $1437(79.0 \%)$ & 1,820 \\
\hline Sending of urgent messages. & Telegram 00 (00\%) & $1,820(100 \%)$ & 1,820 \\
\hline Use of the Bible & Hard copy Bible 334 (18.3\%) & $1486(81.7 \%)$ & 1,820 \\
\hline Dictionary use & Hard copy dictionary 446 (24.5\%) & $1374(75.5 \%)$ & 1,820 \\
\hline Watching of television & Physical TV set 1569 (86.2\%) & $251(13.8 \%)$ & 1,820 \\
\hline Watching of movies & TV set or cinema 326 (67.1\%) & $598(32.9 \%)$ & 1,820 \\
\hline Listening to radio & Physical radio set 1222 (33.3\%) & $324(66.7 \%)$ & 1,820 \\
\hline Playing music & Oral musical set 267 (36.6\%) & $1553(63.4 \%)$ & 1,820 \\
\hline Internet use & Cybercafé 546 (30.0\%) & $1274(70.0 \%)$ & 1,820 \\
\hline Still photography & Still camera 326 (17.9\%) & $1494(82.1 \%)$ & 1,820 \\
\hline Videoing & Video camera 199 (10.9\%) & $1621(89.1 \%)$ & 1,820 \\
\hline Organizer & Organizer 190 (10.4\%) & $1630(89.6 \%)$ & 1,820 \\
\hline Clock & Physical Clock 361 (19.8\%) & $1459(80.2 \%)$ & 1,820 \\
\hline Torch/flash light & Physical torch/flash light 252 (14.0\%) & $1568(86.0 \%)$ & 1,820 \\
\hline Note book/memo pad & Hard copy note book/memo pad 1615 (88.7\%) & $205(11.3 \%)$ & 1,820 \\
\hline Invitation to ceremonies & Hard copy invitation to ceremonies 334 (18.3\%) & $1486(81.7 \%)$ & 1,820 \\
\hline Seasonal greetings & Hard copy seasonal greetings 284 (15.6\%) & $1536(84.4 \%)$ & 1,820 \\
\hline Love letters & Hard copy love letters 352 (19.3\%) & $1468(80.7 \%)$ & 1,820 \\
\hline Calendar & Hard copy calendar 288 (15.8\%) & $1532(84.2 \%)$ & 1,820 \\
\hline
\end{tabular}




\begin{tabular}{|l|l|c|c|}
\hline Activities/tasks & Conventional media tools & Mobile Phone & Total (N) \\
\hline Email & On laptop computer, desktop computer or tablet 379 (20.8\%) & $1441(79.2 \%)$ & 1,820 \\
\hline Audio recording & Hardware audio recording equipment 177 (9.7\%) & $1643(90.3 \%)$ & 1,820 \\
\hline Photo album & Physical photo album 341 (18.7\%) & $1479(81.3 \%)$ & 1,820 \\
\hline Calculator & Physical calculator 181 (9.9\%) & $1639(90.1 \%)$ & 1,820 \\
\hline Reading of newspaper & Hard copy newspapers 128 (7.0\%) & $1692(93.0 \%)$ & 1,820 \\
\hline Online shopping & On laptop computer, desktop computer or tablets 645 (35.4\%) & $1175(64.6 \%)$ & 1,820 \\
\hline Playing of games & Conventional game material 259 (14.2\%) & $1561(85.8 \%)$ & 1,820 \\
\hline
\end{tabular}

The table above shows the breakdown of the data as follows: The entire number of respondents (100\%), the students preferred using the mobile phone to the NIPOST landline phone service. $88.3 \%$ of the students preferred sending message through short message system (SMS) to using the post office as against $11.7 \%$ that preferred posting letters in the post office. $79.0 \%$ preferred receiving small and medium amount of money from parents, relatives and friends through mobile phone services such recharge/top up cards sent through SMS.

A total of $21 \%$ preferred receiving such money through the bank. $100 \%$ of the students preferred sending urgent messages using mobile phones instead of telegram. $81.7 \%$ respondents preferred using the electronic version of the Bible on mobile phone while 18.3 said they preferred using the hard copy of the Bible. $75.5 \%$ of the respondents preferred using the online dictionary on their mobile phones to the hard copy dictionary and $24.5 \%$ preferred using the hard copy dictionary. 13.8 of the respondents preferred watching television on mobile phone while 86.2 said they preferred watching the conventional physical television set. $32.9 \%$ of the respondents preferred watching movies on the conventional television sets, while $67.1 \%$ preferred watching movies on the mobile phone handsets. $66.7 \%$ and $63.4 \%$ preferred listening to radio and playing music on the mobile phone devices as against $33.3 \%$ and $36.6 \%$ that preferred listening to radio and playing music on conventional radio sets and music players respectively.

On internet use, $70 \%$ preferred using mobile phone sets to explore the internet as against 30\% that preferred visiting cyber cafés for internet use. A total of $81.1 \%, 89.1 \%, 89.6 \%, 80.2 \%, 86.0 \%$ and $11.3 \%$ preferred using mobile phone gadgets to perform the functions of still cameras, video camera, organizers, clocks, touch lights/flash lights and notebooks/memo pads while 17.9\%,10.9\%,10.4\%; 19.8\%, 14.0\% and $88.7 \%$ respectively, preferred using the conventional tools meant for the above purposes.

As for invitation to ceremonies, seasonal greetings, love letters, calendar, email and audio recording, $81.7 \%$, $84.4 \%, 80.7 \%, 84.2 \%, 79.2 \%$ and $90.3 \%$ said they preferred using mobile phone gadgets to carry out the above functions respectively. Contrarily, 18.3\%, 15.6\%, 19.3\%, 15.8\%, 20.8 and $9.7 \%$ of the respondents said they preferred using the corresponding conventional tools to perform the above functions respectively. Finally, a total of $81.3 \%, 90.1 \%, 93.0 \%$, $64.6 \%$ and $85.8 \%$ of the respondents preferred using mobile phone handsets for photo album, calculator, and reading of newspaper, online shopping and playing games respectively.

On the other hand, $18.7 \%, 9.9 \%, 7.0 \%, 35.4 \%$ and $14.2 \%$ said they preferred using the corresponding conventional tools to perform the above functions. The data on table 1 shows there are two basic patterns of mobile usage by the students of Delta State University, Abraka. First, they use mobile phone gadgets to carry out the basic functions of telephony, namely making calls and sending text messages.

Secondly, they use mobile phone gadgets to carry out other functions hitherto performed with other conventional media tools. Some of these functions include filming, photography, watching movies, playing music, listening to radio and playing games, among others. This result thus provides answer to the research question on the pattern of Delta State University students' usage of mobile phone.

This result is in tandem with the postulations of Akpan (2005), Oliseh and Igun (2006), Baron (2011), Kun-Hsi (2010), Zulkefly and Baharudin (2009) and Halder (2015) which hold that students use mobile phone for various purposes, of which many of the purposes clearly fall within the purview of other conventional media tools. The data on table 1 further show there is a significant preference for using mobile phone gadgets to carry out functions hitherto performed with the corresponding conventional tools by students of Delta State University, Abraka.

For instance, out of the 28 parameters used to test the students' preference for mobile phones and conventional tools, the students preferred using the mobile phone handsets to perform 25 (89.3\%) of the parameters while they prefer using conventional media tools to perform $3(10.7 \%)$ of the functions. This finding therefore answers the research question on the students' preference for mobile phone and conventional media tools in performing certain functions.

The result therefore suggests clearly that students of the Delta State University, Abraka Main Campus prefer using the mobile phone gadgets to perform several activities which are hitherto the prerogative of other conventional media tools as shown on table 1. The findings are in line with findings of Kasesniemi (2003) and Kun-Hsi (2010), Ronoh (2012), 
Patel and Rathod (2011) which indicated that students prefer the use of mobile phones to other conventional media tools in performing tasks which are traditionally the functions of the conventional media tools.

On the question of the implication of the students' preference pattern on conventional media tools usage, the data show that only $3.7 \%$ of the students preferred using the conventional media tool to perform the traditional functions of those conventional media tools, while $89.3 \%$ preferred using the mobile phone gadgets to perform the traditional functions of the conventional media tools.

The result thus suggests that the students' preference for the mobile phone use in carrying out certain functions performed with traditional media tools has weakened the patronage of Delta State University students for the conventional media tools. The result thus agrees with the postulations of Akpabio (2003), Oliseh and Igun (2006), Cardon (2014), Lenhart et al (2010), Walker (2014) which hold that the use of mobile phone has negative implication on the on the use of several conventional/traditional media tools.

\section{Conclusion}

The study shows that all the students who formed the sample have mobile phone handsets and they use them. This implies a high rate of mobile phone ownership and usage among the students. Majority of the students also preferred using mobile phone to perform the functions, which had hitherto been the exclusive preserve of onventional media. The implication of this preference is that there is the possibility of GSM usage endangering the patronage of conventional media by university students.

\section{Recommendations}

The providers of the conventional media tools should improve on their services to avoid losing patronage of the students. The providers of the conventional media should make their products and services adaptable to mobile phone users in order to boost the students' patronage. Traditional media should endeavour to make their contents amenable to mobile phones in terms of accessibility and interactivity.

\section{References}

Adomi E.E. (2006). Mobile phone usage patterns of Library and Information Science students at Delta State University, Abraka, Nigeria. Electronic Journal of Academic and Special Librarianship, 7(1), 1-11.

Agba, P.C. (2001). Electronic Reporting: Heart of the New Communication Age. Enugu: Snaap Ltd

Akpan. C. (2005). A comparative analysis of the Uses and Gratification of GSM and landline phones among the students of the University of Nigeria' International Journal of Communication, 2(1) 74-80.

Ashiq, H, Mahmood, M. T. and Abdul, S. (2013). Use of mobile communication and its effect on social capital of college going teenagers. International Journal of Research in Humanities, Arts and Literature. 1(3), 45-60

Atala, T. and Umar, M.N (2006). An evaluation of GSM use in news gathering and reporting. 4(2), 149-155.

Patel, A and Rathod, H.S. (2011) Mobile phone usage habits of students commuting From rural areas to nearby town- an exploratory study Of Visnagar (Gujarat-India). Global Journal of Management and Business Research, 11(6), 31-38

Bagozzi , R.P. (2007) The legacy of the technology acceptance model and a proposal for paradigm shift. The Journal of Association for Information System. 8(4), 244-254

Baran. S..J. (2002). Introduction to Mass Communication. Boston: McGraw Hill.

Baron, N.S. (2011). Concerns about mobile phones: A cross-national study. First Monday. 16(8), 56-67

Cardon P.W. and Ying, D. (2014). Mobile phone use in meetings among Chinese professionals: perspectives on multicommunication and civility. Global Advances in Business and Communication Conference \& Journal 3(1), 1-27

Faber R.J. (2000). The irge to buy: a Uses and Gratification Perspective on compulsive buying. In Ratneshwar, S. Mick, D.G and Huffman, C. (Eds). The Why of Consumption. (pp. 177-196). London: Routledge.

Folarin, B. (2001). Theories of Mass Communication: An Introductory Text. Abeokuta: link publications.

Halder, I. (2015). Undergraduate students use of mobile phones: Exploring use of advanced technological aids for educational purpose. Journal of Media and Communication Studies 7(4), 81 - 87

Karim, A. and Oyefolahan, I. O. (2009).Mobile phone appropriation: exploring differences in terms of age, gender and gccupation. The 6th International Conference on Information Technology and Applications (ICITA 2009)

Kasesniemi, E.L. (2003). Mobile messages: Young people and a new communication culture. Tampere: Tampere University Press.

Kun-Hsi, L. (2010). An Exploratory study the expectations from undergraduate students perspectives for the future mobile phone innovations. The Journal of International Management Studies, 5(1), 99-108.

Lacohée, H., Wakeford, N. and Pearson, I. (2003) A social history of the mobile telephone with a view of its future. BT Technology Journal, 21(3) 203-211 
Lenhart, A., Lewis, O. and Rainie, L. (2001). Teenage Life Online. Pew Internet \& American Life Project. (Online) Available: http://www.pewinternet.org/Reports/2001/Teenage-LifeOnline.aspx. (August 16, 2009)

Ling, R. S. (2004) Mobile connection: The cell phone's impact on society. San Francisco: Morgan Kaufmann,

Mogambi, H. (2015). Please pick my call! iniversity students and mobile telephony in Kenya. International Journal of Humanities and Social Science. 5(11), 120-132

Muhammed, H.R.A.I., Umaru, Y and Ahmed, H.T. (2016). Impact of mobile phone usage on academic performance among secondary school students in Taraba State, Nigeria. European Scientific Journal. 12(1) 1857 - 7881

Okoro, N. and Barikui, N. (2006). "A Historical analysis of the communication patterns/strategies of GSM service providers in Nigeria". International Journals of Communications. 2 (5) 90-106.

Oliseh, F.P. and Igun. S.E (2006). Historical analysis of the communication patterns of major mobile companies in Nigeria: MTN, Vmobile, Glo Mobile and M-TEL. Nsukka Journal of Mass Communication. 2 (2), 8I-87.

Reid, D. J. and Reid, F.J.M. (2007). Text or talk? social anxiety, loneliness, and divergent preferences for cell phone use. Cyber Psychology \& Behavior 10(3), 424-435

Ronoh, R.K. (2014). Usage patterns of mobile phones amongst University students in Kenya. International Journal of Science and Research. 3(9), 38-49

Rubin, AM. and Step, (2000). "Impact of Motivation. Attraction and Parasocial Interaction on Talk Radio Listenership. Journal of Broadcasting and Electronic Media. No. 44, 635-654.

Walker, T. (2014). How your cell phone is ripping traditional media apart. (Online) Available: http://www.socialmediatoday.com /content/how-your-cell-phone-ripping-traditional-media-apartSkip to main content (July 10, 2016)

West, R. and Turner, LB (2004). Introducing Communication Theory: Analysis and Application. Boston: McGraw Hill.

Zulkefly, Sheereen N and Rozumah Baharudin (2009). Mobile Phone use Amongst Students in a University in Malaysia: Its Correlates and Relationship to Psychological Health, European Journal of Scientific Research, 37(2) 206-218 
ISSN 2039-2117 (online)

ISSN 2039-9340 (print)
Mediterranean Journal of Social Sciences MCSER Publishing, Rome-Italy
Vol 8 No 2

March 2017 